\title{
The Impact of Criminal Revenue Legalization on Economic Security
}

\author{
Vasyliy Franchuk 1 [0000-0001-5305-3286], Zinaida Zhyvko ${ }^{*}[0000-0002-4045-669 X]$, \\ Aleksandra Kuzior 2 [0000-0001-9764-5320] \\ ${ }^{1}$ Lviv State University of Internal Affairs, Lviv, Ukraine \\ ${ }^{2}$ Silesian University of Technology, Gliwice, Poland \\ "professor2007@ukr.net
}

\begin{abstract}
The article is devoted to the study of the impact of money laundering on the level of economic security of the state. The influence of legalization processes on the level of the shadow economy, foreign exchange, and monetary policy is analyzed. It has been established that corruption is one of the main sources of criminal income. The banking system also suffers losses from money laundering. The impact of illegal cash flows has a twofold effect: on the one hand, confidence in banking institutions is undermined, and on the other hand, regulatory mechanisms in the banking sector are violated. It is worth pointing out that it is incorrect to limit ourselves to disclosing only the consequences of money laundering on the level of economic security. It is necessary to highlight the factors that cause the spread of legalization processes. Corruption is one such factor. Consequently, effective counteraction to the process of shadowing the country's economy and transforming it into a legal one will guarantee the economic security of Ukraine, its independence, true sovereignty, progressive socio-economic development, and contribute to the development of domestic entrepreneurship. The legalization of proceeds from crime is a significant threat to the development of the financial sector of the economy, and, consequently, a threat to the economic security of the state. In addition to the negative moral impact, legalization contributes to the spread of shadow economic processes, reduces the revenue side of the budget, affects the value of the national currency, and reduces the efficiency of legal business.
\end{abstract}

Keywords: money laundering, economic security, shadow economy, legalization of corrupt proceeds.

\section{RELEVANCE OF THE TOPIC}

Leaders of economically developed countries recognize the legalization of proceeds from crime, financing of terrorism, and the proliferation of weapons of mass destruction as a real threat to the economic security of the state. Therefore, the study of the reasons for the spread of legalization processes and their impact on the economy in modern conditions is relevant $[1,2]$.

\section{STATISTICAL ANALYSIS OF THE SHADOW ECONOMY}

In world practice, the level of shadow economy over $40 \%$ of the gross domestic product (GDP) is assessed by experts as critical, since under such conditions the levers of economic regulation become ineffective. FATF estimates the real volume of the shadow economy in highly developed countries at $17 \%$ of GDP, in developing countries $-40 \%$ of GDP, in countries with economies in transition - more than $20 \%$ of GDP According to the Ministry of Economy of Ukraine, the level of the shadow sector of the Ukrainian economy in 2009 amounted to 36\% of the official GDP, and in 2013 the level of the shadow economy of Ukraine amounted to $46 \%$ of GDP (Udovyk M. S. (2014). According to periodicals, the shadow sector in Ukraine in 2012 amounted to 350 billion a year, in 2011 - 446 billion UAH. (34\% of GDP) [3, 4]. In Europe today, the shadow economy is valued at more than $€ 2.1$ billion. It comes under closer scrutiny by the government each time, as national governments seek to balance budgets while avoiding tax increases and spending cuts that could impede economic recovery [5]. The shadow sector is being replenished by several interrelated factors: the predominance of cash payments, lack of transparency in transactions, and limited application of laws and regulations. Typically, the shadow economy offers dubious individual benefits at the expense of others, while creating resistance to increasing global 
"digitalization" and connectivity to electronic payment systems and hampering the public good. The volume of the shadow economy, according to the fiscal authorities, is distributed as follows: UAH 170 billion - wages in "envelopes", UAH 100 billion is the income of asset owners - the withdrawal of non-cash funds in cash or to foreign currency accounts in foreign banks, 35 billion are unofficial payments, 45 billion hryvnias - fixed assets, material resources and services of the shadow sector $[4,6]$. However, according to the publication "Ekonomichna Pravda", such optimistic estimates of the shadow sector (less than a quarter of the forecasted value of nominal GDP for the current year - about UAH 1.5 trillion) may turn out to be significantly underestimated.

It is worth mentioning that according to the latest published official government data, the share of the informal sector in 2010 was about $38 \%$ of official GDP, which has increased after the onset of the crisis by more than ten percentage points $[3,6]$.

\section{THE PROBLEM OF THE SHADOW ECONOMY AND ECONOMIC SECURITY}

We specifically took for comparison the dynamics of the shadow sector over the past decade, and we can argue that today a quarter of Ukraine's official GDP, or 846 billion hryvnias, is shadow transactions. These are the first results of a study of the state of the shadow economy in Ukraine, which was carried out by Ernst \& Young with the support of Mastercard within the framework of the concluded Memorandum of Cooperation with the Ministry of Economic Development, Trade and Agriculture of Ukraine, the National Bank of Ukraine and the State Statistics Service of Ukraine [7]. Ernst \& Young has conducted similar studies in 33 countries of the world, including the Czech Republic, Poland, Slovenia, Slovakia, Croatia, Bulgaria, Bosnia and Herzegovina, Serbia, and other countries. Historically, the level of the shadow economy among these countries ranged from $10.1 \%$ to $26.9 \%$ of GDP [7].

\section{ANALYSIS OF SHADOW ECONOMY RESEARCH}

The study of the problems of ensuring economic security was carried out by scientists: I. Binko, A.Halchynskyi, V. Heyets, Z. Varnalyi, Ya. Zhalilo, Z. Zhyvko, V. Franchuk. At the same time, the implementation of financial monitoring was the subject of research by such scientists: O.M. Bandurka, O.M. Berezhnyi, S.A. Butkevych, S.O. Dmytrov, I.I. Dyakonov, O. O. Hlushchenko, I. V. Kolomiets, O.V. Kravchenko, O.O. Kuryshko, V.A. Nekrasov, I.P. Prykhodko, etc. The problem of the shadow economy is a global-historical phenomenon, characteristic to one degree or another of all social systems. Investigating the functioning of various economic systems, we can conclude that almost any of them is characterized by the existence of such a sphere that contradicts the legal norms in force in society. The interdependence of shadow processes and the economic security of the state, the influence of legalization processes on the level of the shadow economy, foreign exchange, and monetary policy is relevant and littlestudied.

\section{PRESENTATION OF THE MAIN MATERIAL}

Legalization (laundering) of proceeds from crime includes any actions related to the performance of a financial transaction or transaction with proceeds from crime, as well as the commission of actions aimed at concealing or disguising the illegal origin of such proceeds, or the possession of rights to such income, sources of their origin, location, movement, change in their form (transformation), as well as the acquisition, possession or use of proceeds from crime [8].

The laundering of dirty money negatively affects the investment attractiveness of the country, contributes to an increase in the level of the shadow economy, reduces the effectiveness of tax policy, and undermines the work of the financial sector of the economy.

Let us dwell on the assessment [9-11] of the impact of the laundering of "dirty money" on the level of economic security. First of all, budgetary security suffers from the proliferation of money laundering processes. This influence is manifested in a decrease in the effectiveness of the fiscal policy. Unlike other countries, the vast majority of tax revenues in Ukraine are lost due to large-scale tax planning and tax evasion tools. An assessment of tax losses, taking into account the level of the shadow economy, showed that due to tax evasion in 2019 the budget did not receive UAH 452.9 billion. (Figure 1).

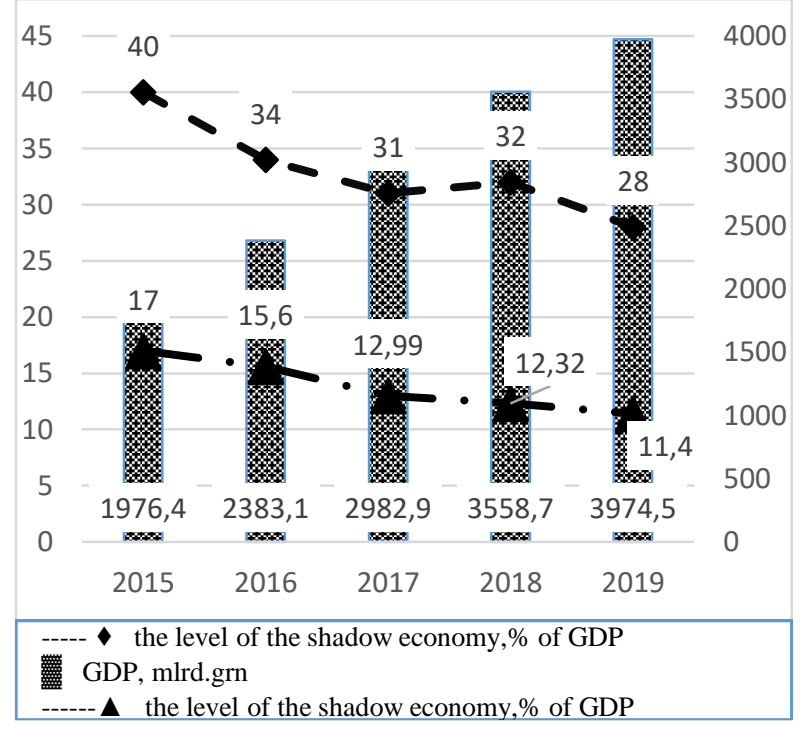

Figure 1 The level of the shadow economy in Ukraine and tax losses from it during 2015-2019\% of GDP 
However, over the last five years, there has been a reduction in the level of tax losses from the functioning of the shadow sector.

Thus, if in 2015 this indicator was at the level of $17 \%$, in $2016-15.6 \%$, in $2017-12.99 \%$, in 2018 $12.32 \%$, and 2019 - respectively, $11.4 \%$ of GDP [12]. The reduction in the level of tax losses became possible due to the decrease in the level of the shadow economy and the tax burden. Average tax losses due to the functioning of the shadow economy in Ukraine in 20152019 amounted to approximately $13.7 \%$ of the official GDP.

In general, the level of Ukraine's GDP for 2018, the level of its monetary economy, etc. were studied during the analysis. The study divides the "cash shadow economy" into "consequential" and "passive", depending on who benefits from it. In the so-called "consequent shadow economy", the two parties to the agreement benefit from it, for example, when paying in cash, the customer does not demand an invoice and receives a discount, and the supplier saves on tax costs without registering the transaction. In the so-called "passive shadow economy", only the seller of this product or service benefits from it, who, for example, sells the product for cash without a check and does not pay taxes.

Research in Ukraine shows that more than a quarter (26.2\%) of the "cash shadow economy" (this is $5.3 \%$ of GDP or UAH 190 billion) is the " consequent shadow economy", where the initiators of the cash settlement are both parties - the seller and the buyer. The rest $(73.8 \%)$ of the total volume of the Ukrainian shadow economy (or $14.4 \%$ of GDP - UAH 512 billion) is a "passive shadow economy" initiated by the seller [13]. The stimulation of non-cash electronic settlements has to significantly reduce the level of the "passive shadow economy".

\section{THE MAIN MEASURES TO COMBAT THE SHADOW ECONOMY}

As the Deputy Chairman of the National Bank of Ukraine Dmytro Solohub noted: "The task of reducing the shadow economy continues to be relevant for Ukraine. In this direction, it is important to consolidate the efforts of business, the Ukrainian government and the National Bank, and all interested state bodies. Due to a decrease in the volume of the shadow economy, only a cash resource, the general level of the country's economy will also grow, because non-cash funds will remain in the economy and, therefore, will work for its development. In particular, this will indirectly contribute to a decrease in the cost of lending to the population and business, and further progress in currency liberalization. The tax base will also grow from transparent business, that is, there will be an increase in revenues to the state budget" [14].
The Central Bank is making a lot of efforts to develop cashless payments and create the habit of paying by bank transfer among the population. As the head of the National Bank notes, work is actively underway to expand the scope of non-cash payments and payment infrastructure in Ukraine. This direction, along with an increase in the level of financial inclusion of the population, is one of the key ones according to the Strategy for the Development of the Financial Sector of Ukraine until 2025. The main goal of the National Bank in this direction is affordable and convenient financial services for all Ukrainians. This will be achieved through the formation and development of a consumer protection system, measures to improve Ukrainian financial literacy, and the development of a cashless economy.

The experience of developing electronic payments in various European countries confirms their positive impact on the economy and the level of its transparency. Ukraine is confidently following the cashless path, and this is facilitated by the development of cashless infrastructure: there are already more than 333,000 POS terminals in the country, 8 out of 10 transactions with payment cards are non-cash. This suggests that Ukrainians are willingly switching to a cashless lifestyle. At the same time, there is significant potential in the development of infrastructure for non-cash payments, and this is especially important for the regions. Today Mastercard, together with partners, is actively developing financial infrastructure and inclusions in Ukraine, introducing solutions for cashless payments in urban social projects, retail, and SMEs. Electronic payments are a powerful driver of a transparent economy, and we consider it important to systematically study the points of positive influence on increasing the level of transparency of the economy in the country, "said Inha Andreyeva, General Director of Mastercard in Ukraine [15].

The negative impact of money laundering is manifested in a decrease in the efficiency of legal business. Using the proceeds from illegal actions to invest in the assets of enterprises allows the latter to quickly increase production capacity, pay increased wages and receive super-profits. This type of money laundering is called corporate laundering. According to analysts, corporate laundering accounts for about $7 \%$ of tax losses.

The study, in addition to assessing the level of the shadow economy, also contains a range of potential measures to reduce the "passive shadow economy" and stimulate the development of cashless payments. In general, the introduction of social payments exclusively in non-cash form, tax incentives, the installation of POSterminals by representatives of small and medium-sized businesses, as well as additional incentives for merchants and consumers to carry out non-cash 
payments, can affect the reduction of the shadow economy. Thus, previous studies in European countries confirm that an increase in the share of non-cash payments by $100 \%$ contributes to a decrease in the level of the shadow economy by $0.6-3.7 \%$ of GDP, and government revenues increase by $0.1-0.8 \%$ of the GDP of the surveyed countries [15].

According to Mastercard, today only $38 \%$ of small and medium-sized businesses in Ukraine provide customers with the opportunity to pay for goods and services by bank transfer, that is, $62 \%$ of enterprises work exclusively with cash. To support small and medium-sized businesses in the implementation of payment infrastructure, Mastercard, together with partners, implements infrastructure projects in different countries of the world. One of the most successful is the Cashless Foundation in Poland, in which more than 130 thousand merchants participate today. Thanks to the fund, 172 thousand terminals were installed in the country. At the same time, $95 \%$ of the program participants are ready to recommend the installation of terminals to other entrepreneurs, which significantly influenced the development of the culture of non-cash payments in Poland [15]

Money laundering poses significant threats to monetary security. The legalization of money forms the sphere of circulation of "black cash" thereby providing the economy with means for quasi-payments. Due to the existence of an uncontrolled money market, macroeconomic indicators are inelastic to respond to changes in the money supply. Therefore, monetary policy runs counter to economic realities. The presence of the shadow economy and the proliferation of legalization processes also confirm the high demand for cash. So, at the end of 2020, the share of cash in the monetary aggregate M3 was 28\%. The use of cash disrupts the demand for legal fund balances. As a result, the spread of legalization of criminal proceeds, a high level of the shadow economy leads to an increase in the level of inflation.

Money laundering also affects the level of currency security of the state, which is manifested in the growth of the level of dollarization of the economy, the devaluation of the national currency, the growing burden of servicing the external public debt. Over the last 20 years, the dollarization of loans and deposits in Ukraine has never been lower than $30 \%$, and the high share of public debt in foreign currency $(71 \%)$ makes Ukraine sensitive to currency and interest rate risks [12].

Corruption in Ukraine is not just a socio-economic phenomenon that is present to varying degrees in many countries of the world. It is a system of relations that permeates all spheres of society, including the economy. The study of the level of corruption in Ukraine showed that despite strong political statements and some anticorruption decisions, the level of corruption is quite high. Ukraine is still included in the group of corrupt countries (Figure 2).

As can be seen from Figure 2, in the Global Corruption Perceptions Index for 2019, Ukraine received 30 points out of 100 possible, ranking 126th out of 180 countries, along with Kyrgyzstan, Azerbaijan, and Djibouti [16]. This, of course, is an unacceptably low figure for such a large European country with a population of over 40 million people, which is Ukraine. This level of corruption threatens the political and economic stability of Ukraine.

The relationship between corruption and economic security is manifested through a number of negative consequences of economic development, which in the context of globalization have an extremely destructive effect on the country's economy. Corruption "washes away" funds from the national economy, thereby reducing its efficiency and hinders development, and the funds received from the use of corruption schemes are used for further investment, and the purchase of luxury houses, VIP cars, yachts, precious metals, and stones, antiques, securities, exquisite relaxation, and other personal needs.

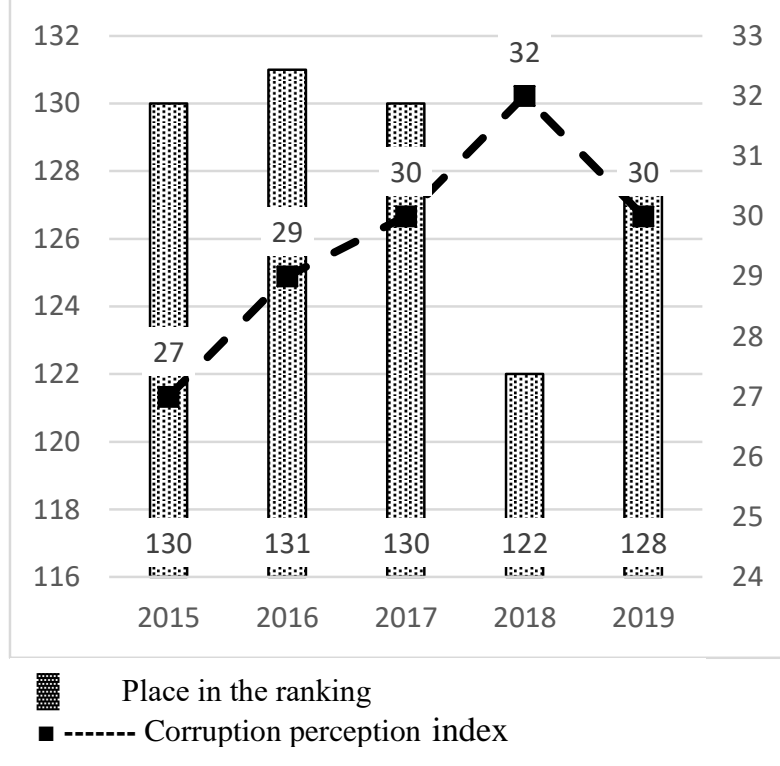

Figure 2 Corruption perception index in Ukraine and place in the world ranking during 2015-2019 [17]

The institution of financial investigation is an effective anti-corruption mechanism. The State Financial Monitoring Service is the financial intelligence unit of Ukraine and is taking enhanced measures to combat money laundering, terrorist financing, and the proliferation of weapons of mass destruction. Today, one of the priorities of the State Financial Monitoring Service is to investigate the laundering of corruption proceeds, embezzlement and 
misappropriation of funds and state property, search and freezing of the property of former Ukrainian officials.

An important indicator of the effectiveness of anticorruption policy is the amount of funds returned for committing corrupt acts. As can be seen from Figure 2, the amount of financial transactions related to the laundering of corruption proceeds is critically small.

For Ukraine, it is necessary to develop its concept of legalizing the shadow economy, taking into account the peculiarities of the domestic economy, economic and socio-political conditions, the peculiarities of the manifestation of the shadow economy. When developing your concept of legalizing the shadow economy, one should take into account that the basis of any model for assessing moral damage caused by the shadow economy is the fact that moral hazard is a direct consequence of the economic benefit for the party that causes it. From the point of view of the shadow sector of the economy, the amount of moral hazard is the amount of economic benefits that can be obtained as a result of illegal actions. Let us dwell on the example given by O. Vashchenko [18], in particular, when an individual does not pay tax on income received outside the main place of work. The individual believes that the amount of potential penalties is not equivalent to the amount that would be saved as a result of non-payment of income tax. In mathematical form, this thesis can be formulated as follows: the coefficient of economic benefit $m h k$ will be equal to the ratio of the amount of economic benefit $p E$ (the hidden amount is the amount of unpaid tax) to the amount of losses from illegal behaviour $n E$ (that is, the amount of penalties). In other words, we have determined the amount of moral hazard of a person in the process of hiding income tax.

$$
\operatorname{mh~} \mathrm{k}=\frac{p E}{n}
$$

The resulting value of the amount of moral hazard should be interpreted as follows:

$m h k<1$ - the moral hazard in this operation is minimal and can be ignored when determining the risk of the operation. That is, for such actions of an economic entity, it is not worth increasing the amount of penalties;

mh $k=1$ - moral hazard is present, but its implementation depends on the behaviour of the economic entity. In this case, changing penalties is not a top priority;

$1<m h k<1.2$ is the first of the zones of increased risks of realization of moral damage under the transaction. The state needs to introduce some additional restrictions or conditions on liability for such an action in order to neutralize the positive effect of the opportunistic behaviour of an economic entity; $1.2<\mathrm{mh} \mathrm{k}<1.5$ is the next, more critical area from the point of view of the implementation of moral damage. The benefits of implementing opportunistic behaviour are fairly obvious for an economic entity. A number of measures should be taken to equalize the positive and negative effects of this behaviour of an economic entity and to exercise additional control over such behaviour of economic entities by the state;

$m h k>1.5$ - in this case, the benefits from the implementation of moral damage are obvious for the economic entity, it determines a critically large value of this risk. It is urgently necessary to increase the amount of responsibility for this type of economic actions of subjects [18]. Evidently, this technique is not entirely ideal, however, it allows us to outline the main approaches to assessing the level of moral damage for a particular action of an economic entity. We agree with the author [18] that moral risks can have a significant impact on the behaviour of economic agents and act as a fundamental factor in the existence of the shadow sector. The essence of the concept of "risk" is the probability of the realization of a potential hazard under certain circumstances and the negative consequences of this realization, that is, the risk is a measure (measurement) of the expected failure in the process of a certain type of activity (in our case, the shadow economy) or an activity aimed at achieving success for low probability. Mathematical reflection of risk: the ratio of the number of dangerous events with damage caused (n) to their maximum possible number for a certain period of time $(\mathrm{N})$.

$$
\mathrm{T}=\frac{n}{N}
$$

An important aspect of risk theory is the fact that each hazard has a certain probability of being realized. The moral risks of the state should be understood as rational actions of economic entities with the maximization of their utility to the detriment of the state due to the asymmetry of information, manifested in the illegal behaviour of economic entities. Their neutralization will significantly reduce the volume of the shadow economy.

The possibility of creating the necessary conditions for further painless legalization of temporary participants in "shadow" entrepreneurship will first of all depend on whether the power structures will be able to distinguish and rationally differentiate "shadow" offenses by the level of their objective social danger and economic damage, justly applying, respectively, in committed offenses differentiated sanctions. That is, we are talking about those subjects of the "shadow" economy, whose activities did not cause significant damage to society, in contrast to the really dangerous criminal and violent element of organized crime. 
So, the priority in the strategy of de-shadowing the Ukrainian economy remains to accelerate its economic development. Taking into account the real state of the domestic economy, first of all, we are talking about anticrisis measures, about structural and innovative transformations in the country in the short and long term.

In particular, the restructuring of the economy of Ukraine should ensure: (1) (1) acceleration of innovation processes in society; (2) reducing tax pressure on businesses; (3) an increase in the proportion of scientifically capacious sectors of the economy and advanced industries; (4) the cycle of "creation development - introduction into production" of new products should shrink and approach the modern characteristics of European countries; (5) domestic products must meet European quality standards. Only under such conditions, Ukraine will really be on a par with the developed countries of Europe. Consolidation of Ukrainian society around the idea of accelerated modernization of domestic production, creation of competitive products according to world quality standards is becoming a vital component of Ukraine's exit program from the financial and economic crisis [18], as evidenced by the last few years in the direction of state regulation. Only the complex application of the above measures will stimulate the process of de-shadowing the economy and will lead the process of legalization of income, promote the development of entrepreneurship

\section{CONCLUSIONS}

To improve economic relations: protection of domestic markets; stimulating domestic producers; unblocking the processes of economic reproduction; counteraction to shadow manifestations in the form of pseudo-dumping, illegal or pseudo-legal export of intellectual property objects; import of obsolete technologies at the expense of the budget as a result of illegal protectionist actions of employees of registration, permitting and control bodies; optimization of control mechanisms over the procedure of tariff and non-tariff regulation, licensing, quotas for export-import operations; the application of anti-dumping measures to unscrupulous partners and non-resident partners, whose countries apply discriminatory trade and restrictive measures to Ukrainian goods, should be carried out in the following directions [19]:

1. Introduction of a comprehensive nationwide system of counteraction to unfriendly discriminatory measures in Ukraine by other countries, which includes:

a) creation of a centralized database of unfriendly discriminatory trade and restrictive measures against Ukrainian goods by other countries;

b) development of a system (recognized in the world) of standard measures of response to discriminatory trade and restrictive sanctions against
Ukrainian goods from other countries and legally defined situations, responsible officials, the system of sanctions, and the procedure for their mandatory application;

c) creation of a nationwide system of control over the timely and commensurate response of the relevant state bodies to discriminatory trade and restrictive measures against Ukrainian goods by other countries.

2. Implementation of a nationwide system of protection of the domestic market for intellectual property objects and scientific and technological potential of the state, which includes:

a) creation of a unified nationwide system of accounting and circulation of high-tech intellectual property objects;

b) introduction of a unified state system of inventory of current scientific and technical developments, as well as those at the completion stage, with the aim of their timely registration, pre-sale assessment, and formation of a legal market for intangible assets;

c) creation of a nationwide accounting system, presale assessment of high-tech developments, and other intangible assets created at the expense of budgetary funds.

3. The domestic market of high-tech goods in Ukraine is also insufficiently protected. Quotas, antidumping investigations, and countervailing duties provided for by international agreements are weakly applied to the importer. The volume of certification of high-tech products imported to Ukraine has recently decreased several times. Outdated means and systems of informatization are often purchased, incompetence, mistakes and dishonest and corrupt acts of officials in the selection of supplier firms and the conclusion of international contracts take place.

4. To strengthen the protection of domestic producers from unscrupulous partners, to counter illegal protectionist manifestations on the part of business entities and employees of registration, permitting, and regulatory authorities, to ensure the development of the domestic market of Ukraine, it is necessary:

a) to develop and implement a nationwide support system for information, consulting, and marketing services for economic entities;

b) to increase the level of taxation of operations for the export of raw materials that are in short supply on the domestic market and refraining from setting a duty on the purchase of raw materials supplied by foreign customers for processing in the customs territory of Ukraine;

c) prompt response and lag of export prices from the prices of the domestic market, with the establishment of 
the amount of taxation of export operations depending on the difference between these prices.

d) to develop and introduce organizational and legal mechanisms: quotas and licensing of imported goods that can be produced in Ukraine; counteracting the attempts of economic entities - monopolists to maximize profits by creating an artificial deficit for dumping or pseudo-dumping export conditions; introduce a special tax on their imports, discriminatory restrictive actions on goods originating from Ukraine;

e) to start the formation of a national information databank on unreliable and insolvent foreign enterprises - partners of economic entities of Ukraine, as well as companies entered in the specified databank by indicators of payment discipline;

f) to form a data bank of domestic business entities that violated the terms of return of foreign exchange earnings from abroad, were allowed to dumping, pseudo dumping operations, and other offenses.

Consequently, effective counteraction to the process of shadowing the country's economy and transforming it into a legal one will guarantee the economic security of Ukraine, its independence, true sovereignty, progressive socio-economic development, and contribute to the development of domestic entrepreneurship.

The legalization of proceeds from crime is a significant threat to the development of the financial sector of the economy, and, consequently, a threat to the economic security of the state. In addition to the negative moral impact, legalization contributes to the spread of shadow economic processes, reduces the revenue side of the budget, affects the value of the national currency, and reduces the efficiency of legal business.

\section{REFERENCES}

[1] Korystin, O.Y. Svyrydiuk, N.P. Mihus, I.P. Likhovitskyy, Y.O. and Mitina, O.M. (2020), "Money laundering: macroeconomic assessment methods and current trend in Ukraine", Financial and credit activities: problems of theory and practice, vol. 1 (32), pp. 341-350, DOI: 10.18371/fcaptp.v1i32.200865

[2] Korystin, O.Y. Nekrasov, V.A. Krivolapchuk, V.O. and Sviridyuk, N.P. (2019), "The Phenomenology of Money Laundering in Ukraine", Financial and credit activities: problems of theory and practice, vol. 2 (29), pp. 374-382, DOI: $10.18371 /$ fcaptp.v2i29.171949

[3] Ukraine has a shadow economy of 350 billion. Podatkova hazeta "Ukrainska pravda", Ekonomichna pravda, available at: http://www.epravda.com.ua/news/2012/08/19/33 2306/
[4] Zhyvko, Z.B. and Zasadko, V.V. (2013), "Ensuring economic security in the context of countering the influence of the shadow economy", Gosudarstvennoe upravlenie, Elektronnyj vestnik MGU im. Lomonosova, no 37, aprel.

[5] Scheider, F. Kearney, A.T. and Johannes, Kepler (2013), "The Shadow Economy in Europe", Universitat Linc, JKU.

[6] Movchan, M. "The volume of Ukraine's shadow economy is UAH 350 billion, half of which is salaries in "envelopes", available at: http://wallnews.info/news/2012/08/20/180070

[7] Doslidzhennia tinovoi ekonomiky v Ukraini: maizhe chvert VVP - abo 846 mlrd hryven perebuvaie $\mathrm{v}$ tini [Study of the shadow economy in Ukraine: almost a quarter of GDP - or 846 billion hryvnia - is in the shadows, available at: https://bank.gov.ua/ua/news/all/doslidjennyatinovoyi-ekonomiki-v-ukrayini--mayje-chvertvvp--abo-846-mlrd-griven--perebuvaye-v-tini

[8] 'On prevention and counteraction to legalization (laundering) of proceeds from crime, financing of terrorism and financing of proliferation of weapons of mass destruction", Zakon Ukrainy vid 06.12.2019, no 361-IX, available at: https://zakon.rada.gov.ua/laws/card/361-20

[9] Rayan Abdelgader Elhassan, Adil Yousif and Taj Elsir Hassan Suliman (2021), "Assessment of Knowledge Management Application in Banking Sector of Sudan: Case Study Farmer's Commercial Bank", International Journal of Information Engineering and Electronic Business, vol. 13, no. 4, pp. 1-19, DOI: $10.5815 /$ ijieeb.2021.04.01

[10] Mehran Junejo, Asif Ali Laghari, Awais Khan Jumani, Shahid Karim and Mansoor Ahmed Khuhro (2020), "Quality of Experience Assessment of Banking Service", International Journal of Information Engineering and Electronic Business, vol. 12, no. 6, pp. 39-50, DOI: 10.5815/ijieeb.2020.06.04

[11] Umang Dhuri and Nilakshi Jain (2020), “Teaching Assessment Tool: Using AI and Secure Techniques", International Journal of Education and Management Engineering, vol. 10, no. 3, pp. 12-21, DOI: $10.5815 /$ ijeme.2020.03.02

[12] Rodchenko, S.S. Leliuk, N.Ie. and Vysotska, I.B. "The influence of the shadow economy on the formation of tax gaps", SWorld Journal, issue 6, part 3, pp. 20-23. 
[13] Trends and prospects for the development of the financial system of Ukraine, National Bank of Ukraine, available https://bank.gov.ua/admin_uploads/article/DS

[14] NBU data for 2019, available at: https://bank.gov.ua/ua/news/all/platijnainfrastruktura-2019-rik

[15] Mastercard SME CEE Monitor, (2019), available at: https://www.mastercard.com/news/europe/

[16] Corruption Perceptions Index 2019, available at: https://ti-ukraine.org/research/indeksspryjnyattya-koruptsiyi-2019/
[17] "Official site of the State Financial Monitoring Service of Ukraine, available at:https://fiu.gov.ua/

[18] Kirzhetskyi, Yu.I. (2013), Shadow economy and directions of its overcoming in Ukraine [Tinova ekonomika ta napriamy yii podolannia v Ukraini], monohrafiia, Liha-Pres, Lviv, Ukraine.

[19] Economic security [Ekonomichna bezpeka] (2009), navch. posib., za red. Varnaliia, Z.S., Znannia, Kiev, Ukraine. 